\title{
Barbara Hryszko
}

\section{Noël Coypel's Educational Journey to Rome at the end of 1672 and the Beginning of 1673}

\author{
Podróż dydaktyczna Noëla Coypela do Rzymu \\ na przełomie lat 1672/1673
}

\section{Abstract}

The aim of this article is to present the circumstances of Noël Coypel's appointment as rector of the French Academy in Rome and to trace the route of his didactic journey from Paris to Rome with the Prix de Rome scholars entrusted to him. The paper is an attempt to answer the following questions: why a more difficult route through the Alps was chosen (and not, for example, a river and sea route), in what way was the journey educational, and what role did the documents given to Coypel play in securing the expedition. The article is based on an analysis of administrative records during the reign of Louis XIV, lists of superintendents and directors of the French Academy in Rome, accounts of royal buildings, and minutes of the Royal Academy of Painting and Sculpture in Paris. The paper uses the analytical method, the comparative method, the synthetic method, source criticism, argumentum ex silentio inference, and the geographical method when discussing the itinerary.

Although the trip was purposeful and related to Coypel's new position, he designed it in such a way as to not so much get to the destination 
quickly, but to show his students as much as possible. Coypel introduced the royal scholars to masterpieces of painting and sculpture at centers along a route through Dijon, Lyon, Chambéry, the Mont Cenis Pass, Turin, Milan, Bologna and Florence. The crossing of the Alps, though dangerous, was most often chosen because of the artistic reputation of the cities there. The trip was educational at the expense of comfort or safety. Coypel, as a guide and teacher (paidagōgós) led his charges by overseeing their learning during and through the journey. Wandering to the Eternal City was part of a painter's education (paideía) in the seventeenth century and was part of Coypel's didactic work allowing young people to be inspired by direct exposure to masterpieces. The journey had an eminently didactic and artistic character, but also an initiatory one, as it gradually initiated and prepared the students for the experience of Rome, the center of artistic life at that time.

Keywords: Noël Coypel, didactic journey, Royal Academy of Painting and Sculpture, French Academy, Rome, Paris

\section{Abstrakt}

Celem artykułu jest przedstawienie okoliczności mianowania Noëla Coypela na stanowisko rektora Akademii Francuskiej w Rzymie oraz prześledzenie trasy jego dydaktycznej podróży z Paryża do Rzymu, którą przemierzał wraz z powierzonymi sobie stypendystami Prix de Rome. Tekst jest próbą odpowiedzi na pytania: Dlaczego obrano trudniejszą trasę przez Alpy (a nie np. rzeczno-morską)? Na czym polegał edukacyjny charakter wędrówki? Jaką rolę w zabezpieczeniu wyprawy odgrywały przekazane Coypelowi dokumenty? Artykuł bazuje na analizie dokumentacji administracyjnej za panowania Ludwika XIV, listach nadintedntentów i dyrektorów Akademii Francuskiej w Rzymie, rachunkach budynków królewskich, protokołach Królewskiej Akademii Malarstwa i Rzeźby w Paryżu. W artykule zastosowano metodę analityczną, porównawczą, syntetyczną, krytykę źródeł, wnioskowanie argumentum ex silentio, a przy omawianiu trasy podróży - metodę geograficzną. Choć podróż była celowa, związana z objęciem stanowiska, to jednak Coypel tak ją poprowadzit, by nie tyle szybko znaleźć się u celu, ale by jak najwięcej pokazać swoim studentom. Coypel zapoznawał królewskich stypendystów z arcydziełami malarstwa i rzeźby w ośrodkach na trasie wiodącej przez Dijon, Lyon, Chambéry, przełęcz Mont Cenis, Turyn, Mediolan, Bolonię i Florencję. Przeprawa przez Alpy, mimo iż niebezpieczna, była najczęściej obierana ze względu na renomę artystyczną tamtejszych miast. Podróż była edukacyjna, kosztem komfortu czy bezpieczeństwa. Coypel jako przewodnik i nauczyciel (paidagōgós) prowadził swoich podopiecznych, czuwając nad ich nauczaniem podczas i dzięki podróży. Wędrowanie do Wiecznego Miasta było częścią edukacji (paideía) malarza w wieku XVII 
i stanowiło element pracy dydaktycznej Coypela pozwalającej młodzieży czerpać inspiracje z bezpośredniego obcowania z arcydziełami. Wędrówka miała wybitnie dydaktyczno-artystyczny charakter, ale także inicjacyjny, bo wtajemniczała stopniowo i przygotowywała na doświadczenie Rzymu centrum ówczesnego życia artystycznego.

Słowa klucze: Noël Coypel, podróż dydaktyczna, Królewska Akademia Malarstwa i Rzeźby, Akademia Francuska, Paryż, Rzym

All roads followed by the 17th-century artists, especially those connected with academic art, led to Rome. The Eternal City was a particular magnet for young artists, so it is not surprising that the city on the Tiber was the main destination for artistic journeys in the modern era. ${ }^{1}$ The need to educate artists in Rome, the city teeming with both ancient and modern works of art, was also acknowledged by art patrons, including Louis XIV, King of France, who - in 1666 - established the French Academy in Rome (Académie de France à Rome). Charles Errard (1606-1689), its first rector, for over 6 years was responsible for the work of young Roman artists who had been awarded the scholarship in this city. In 1672,

1 This issue is discussed in extensive subject literature, e.g.: Ludwig Schudt, Italienreisen im 17. und 18. Jahrhundert, Römische Forschungen der Bibliotheca Hertziana, Band 15 (Wien, München: Schroll, 1959); Attilio Brilli, Le voyage d'Italie: histoire d'une grande tradition culturelle du XVI e au XIX e siècle (Paris: Flammarion, 1989); Jean Boutier, "Le Grand Tour: Une pratique d'éducation des noblesses européennes (XVIe - XVIIIe siècles)," in Le Voyage à lépoque moderne, préface Lucien Bély (Paris: Presses de l'Université de Paris-Sorbonne, 2004), 7-22; Vito Castiglione Minischetti, Giovanni Dotoli, Roger Musnik, Le voyage français en Italie des origines au XVIIIe siècle: bibliographie analytique, Bibliothèque du voyage français en Italie, 1 (Fasano, Paris: Schena, Lanore, 2006); Laurent Bolard, Le voyage des peintres en Italie au XVIIe siècle (Paris: Les Belles Lettres, 2012). The impact of printed guidebooks on travels to Italy is discussed in: François Brizay, "Peut-on mesurer l'influence qu'eurent en France les guides et récits de voyage en Italie du milieu du XVIIe siècle à la fin du XVIIIe siècle?", in La culture du voyage: pratiques et discours de la Renaissance à l'aube du XXe siècle, sous la direction de Gilles Bertrand (Paris: L'Harmattan, 2004), 121-146. The French guidebooks to Italy from the 17th century are discussed in: idem, "La présentation de l'Italie dans les guides imprimés en français au XVIIe siècle," in Les guides imprimés du XVIe au XXe siècle. Villes, paysages, voyages. Actes du colloque tenu à Paris VII-Denis Diderot, les 3-5 décembre 1998, sous la direction de Gilles Chabaud, Évelyne Cohen, Natacha Coquery, Jérôme Penez (Paris: Belin, 2000), 359-376. The method of writing guidebooks for travellers is described in: idem, Touristes du Grand Siècle. Le voyage d'Italie au XVIIème siècle (Paris: Belin, 2006). 
at the age of 66, he asked for permission to resign from this post ${ }^{2}$ and nominated his 44-year-old friend Noël Coypel $(1628-1707)^{3}$ as his successor [Fig. 1]. However, Errard's choice was not binding, as the final decision belonged to Charles Le Brun, at that time both Chancellor and Rector of the Royal Academy of Painting and Sculpture in Paris. Coypel, a man of great talent and great ambition, was in his element in court circles and enjoyed the favour of First Painter to the King. ${ }^{4}$ Undoubtedly, this was a decisive factor in appointing him to the position of a new rector of the Academy in Rome; this appointment was a direct reason of his taking a leave of absence from his duties at the Academy in Paris (29 October). ${ }^{5}$ The winners of the Prix de Rome competition - Alexander Ubeleski, Jean Jouvenet, Charles-François Poerson, Michel Monnier and Jean Tortebat ${ }^{6}$ - were entrusted to his care during the journey.

While preparing for the journey to Rome, Coypel did not fail to show his gratitude to Le Brun, the Academy's main decision-maker. A convenient opportunity for it came with his name day falling on 4 November. The day before, Coypel had exotic orange trees transported to the estate of

2 His request was motivated by the deteriorating state of his health and difficulties in maintaining discipline at the Academy: Lettres, instructions et mémoires de Colbert publiés par Pierre Clément, vol. 5, Fortifications, Sciences, Lettres, Beaux-Arts, Bâtiments (Paris: Imprimerie Impériale, 1868), 280, 293, 313-314; Albert Lecoy de La Marche, L'Académie de France à Rome. Correspondance inédite de ses directeurs, précédée d'une étude historique (Paris: Didier, 1874), 9-10.

3 Lecoy de La Marche, L'Académie de France à Rome, 10; Auguste Castan, "Les premières installations de l'Académie de France à Rome d'après le plus ancien inventaire du mobilier et des travaux de cette institution," Mémoires de la Société démulation du Doubs, 4 (1889): 159; Henry Lapauze, Histoire de l’Académie de France à Rome, vol. 1: 1666-1801 (Paris: Librairie Plon, 1924), 25.

4 Coypel's personality is discussed in: Lapauze, Histoire de l'Académie de France, 36; Jean-Paul Alaux, L'Académie de France à Rome. Ses directeurs, ses pensionnaires (Paris: Duchartre, 1933), 28.

5 "Ce mesme jour [29 Octobre 1672] Monsieur Coypel a prix congé de la Compagnie pour le voyage de Rome, où il est envoyé du Roy pour la conduite de l'Académie Fransoise establie en ceste ville là": Paris, École Nationale Supérieure des Beaux-Arts, Ms. 1, Procès-verbaux de l'Académie royale de Peinture et de Sculpture, vol. 1, [29 Octobre 1672]. Cf.: Procès-verbaux de l'Académie Royale de Peinture et de Sculpture 1648-1792, publiés pour la Société de l'Histoire de l'Art français d'apres les registres originaux conservés à l'École des Beaux-Arts par Anatole de Montaiglon, vol. 1: 1648-1672 (Paris: J. Baur, 1875), 400-401; Correspondance des directeurs de l'Académie de France à Rome avec les Surintendants des Bâtiments, publiée par Anatole de Montaiglon, vol. 1: 16661694 (Paris: Charavay Frères, 1887), 38. This issue is also discussed in: Lapauze, Histoire de l'Académie de France, 37.

6 On the certificates confirming being awarded the Royal prize: Paris, École Nationale Supérieure des Beaux-Arts, Ms. 480, L'Etablissement de l'Académie royale de Peinture et de Sculpture [Du 29 iour d'Octobre 1672, unnumbered pages]. 
First Painter to the King in Montmorency and arranged them along the path in the garden so that on the morning of St. Charles' day, Le Brun's patron saint, he could walk down the alley flanked by orange trees. ${ }^{7}$ Following Jean Rou's account, ${ }^{8}$ this courtly gesture has been erroneously interpreted in subject literature as a kind of a bribe Coypel offered to Le Brun to secure his new position in Rome. ${ }^{9}$ This is contradicted by the fact that the painter's appointment took place earlier, i.e. in October, and Coypel presented his elaborate gift to Le Brun in November, which should, therefore, be treated as a token of his gratitude, and not a bribe. The only thing that Coypel might have possibly hoped to obtain by this ostentatious and extravagant gift was the permission to take his 12-yearold son Antoine and his two brothers-in-law, Louis Henri Hérault and Charles Antoine Hérault, to Rome. Apart from the family members of the newly appointed rector, the passport issued on 9 November 1672 by Jean Baptiste Colbert listed: Simon Chupini, an architect, Benoît Farjat, an engraver, de Voulan, a sculptor, ${ }^{10}$ together with the five above mentioned Prix de Rome awardees; ${ }^{11}$ the group was accompanied by servants carrying luggage, who were called valets in the passport.

In order for Noël Coypel to successfully complete the tasks set by the French monarch, he was provided with official letters to facilitate the journey, i.e. the passport addressed to the local authorities in the towns

7 "Un matin, qui était le 4 novembre, jour de sa fête, Le Brun put se promener, dans son domaine de Montmorency, entre deux rangées d’orangers que Coypel y avait fait transporter de la veille au lendemain": Lapauze, Histoire de l'Académie de France, 36.

8 Mémoires inédits et opuscules de Jean Rou (1638-1711), publiés pour la Société de l'histoire du protestantisme français, d'après le manuscrit conservé aux archives de l'État à La Haye par Francis Waddington, (Paris: Agence centrale de la société, 1857), 21-22. Cf.: Correspondance des directeurs de l'Académie de France à Rome, vol. 1, 36-37.

9 Alaux, L'Académie de France à Rome, 28; Lapauze, Histoire de l'Académie de France, 36; Mickaël Szanto, Le dessin ou la couleur? Une exposition de peinture sous le règne de Louis XIV, préface d'Antoine Schnapper (Genève: Droz, 2008), 27.

10 They were listed in the passport, and mentioned by: Lapauze, Histoire de l'Académie de France, 39-40. See also: Franchi-Verney della Valetta, L'Académie de France à Rome, 1666-1903 (Paris: Fischbacher, 1904), 35.

11 "Envoyant à Rome le Sieur Coypel, l'un de nos Peintres ordinaires, avec les nommés Antoine Coypel, son fils, Charles Hérault, Louis-Henri Hérault, Simon Chupini, Farjat, Charles Poerson, Alexandre, Tortebat, Pierre Monnier, Voulan et Jouvenet": Paris, Archives Nationale de France, Archives de la Marine, Dépêches concernant le commerce, 1672, fol. 329. Cf.: Correspondance des directeurs de l'Académie de France à Rome, vol. 1, 39; Lettres, instructions et mémoires de Colbert, 541-542; Lapauze, Histoire de l'Académie de France, 30, 37; Alaux, L’Académie de France à Rome, 28; Castan, "Les premières installations de l'Académie," 167 , note 1. 
of France that lay along the itinerary ${ }^{12}$ and two letters to the French deputies residing in Turin and Florence. The first was Ennemond Servien, residing at the court of Carlo Emmauele II (1638-1675), and the second was Luigi Strozzi, guarding the interests of the Sun King at the court of Cosimo III Medici (1670-1723). ${ }^{13}$ In addition, on November 11, Coypel was paid 500 livres from the royal treasury. ${ }^{14}$

Surviving documents do not provide data to establish a precise chronology of the journey. One thing is certain. In the group of travelers, besides the future rector of the French Academy in Rome, there were 10 people, including five Prix de Rome winners, and some servants. ${ }^{15}$ Coypel probably set out from the French capital shortly after 11 November and

12 Paris, Archives Nationale de France, Archives de la Marine, Dépêches concernant le commerce, 1672, fol. 329. Cf.: Correspondance des directeurs de l'Académie de France à Rome, vol. 1, 39.

13 Paris, Archives Nationale de France, Archives de la Marine, Depéches concernant le commerce, 1672, fol. 330. Cf.: Correspondance des directeurs de l'Académie de France à Rome, vol. 1, 40; Correspondance administrative sous le règne de Louis XIV entre le cabinet du roi, les secrétaires d'Etat, le chancelier de France et les intendants et gouverneurs des provinces, les présidents, procureurs et avocats généraux des parlements et autres Cours de Justice, par Georges Bernard Depping, vol. 4 (Paris: Imprimerie Nationale, 1855), 592; Lettres, instructions et mémoires de Colbert, 341. On 15 December 1672, Ennemond Servien wrote to Colbert thanking him for the letter he received from him, which Coypel handed to him: Correspondance des directeurs de l'Académie de France à Rome, vol. 1, 40-42. Cf.: Lapauze, Histoire de l'Académie de France, 37. This journey was the subject of my other study conducted from a different perspective: Barbara Hryszko, "Podróż artystyczna Aleksandra Ubeleskiego z Paryża do Rzymu," Barok XX/2, 40 (2013): 47-58; eadem, Le Peintre du Roi. Aleksander Ubeleski (1649/16511718) - malarz polskiego pochodzenia we Francji i jego dzieła (Kraków: WAM, Ignatianum, 2016), 40-42.

14 Comptes des Bâtiments du Roi sous le règne de Louis XIV, publiées par Jules Guiffrey, vol. 1, Colbert. 1664-1680 (Paris: Imprimerie Nationale, 1881), 648; Correspondance des directeurs de l'Académie de France à Rome avec les surintendants des bâtiments, publiée par Anatole de Montaiglon et Jules Guiffrey, vol. 6, 1721-1724 (Paris: Charavay Frères, 1896), 432; Lecoy de La Marche, L'Académie de France à Rome, 17. Each of the scholarship recipients received 200 livres. See also: Hryszko, "Podróż artystyczna Aleksandra Ubeleskiego," 49; eadem, Le Peintre du Roi. Aleksander Ubeleski, 40.

15 On the importance of travel to Rome for artists in the 17th century: Jacques Thuillier, " "Il se rendit en Italie». Notes sur le voyage à Rome des artistes français au XVIIe siècle", in «Il se rendit en Italie». Etudes offertes à André Chastel (Rome-Paris: Elephante-Flammarion, 1987), 321-336; Gilles Montègre, "Artistes et voyageurs français à Rome à l'apogée du Grand Tour: les raisons d'être d'une dépendance réciproque," in Voyage d'artistes en Italie du Nord XVIe-XIXe siècles, sous la direction de Véronique Meyer et Marie-Luce Pujalte-Fraysse (Rennes: Presses universitaires de Rennes, 2010), 33-44; Hryszko, "Podróż artystyczna Aleksandra Ubeleskiego," 47-58; eadem, Le Peintre du Roi. Aleksander Ubeleski, 40-42. 
before 12 December 1672, when his presence in Turin is attested.$^{16}$ However, it is not certain by what route the painter arrived in the capital of Piedmont. It seems that he visited Dijon, Lyon and Chambéry on his way, then, heading over the Mont Cenis pass, he crossed the Alps and arrived in Turin through the Susa Valley. ${ }^{17}$

In the capital of the Duchy of Savoy, after checking in with Ennemond Servien, Coypel, along with the other artists, was shown around by an unspecified relative of the ambassador. ${ }^{18}$ As a teacher, Coypel then had a convenient opportunity to instruct his students, to comment on the monuments they saw, and to point out works of art suitable to become sources of inspiration for the young artists. The only certain point in the artistic "tour de Turin" by Coypel and his companions was the suburban hunting palace called Venaria Reale, visiting which was mentioned by the French deputy, Servien, in a letter addressed to Colbert dated December $15,1672 .{ }^{19}$ It can be assumed that the artists did not also miss the royal palace, built for Carlo Emmanuele II between 1646 and 1658, as well as the Chapel of the Shroud (Cappella della Sacra Sindone) freshly erected between 1667 and 1668, designed by Guarino Guarini. ${ }^{20}$

Before he set off on further journey, Noël Coypel received two letters from the deputy to facilitate his journey and ensure that it was educational. The first letter was addressed to the deputy's son, Rev. HuguesHumbert Servien (d. 1723), living in Rome. ${ }^{21}$ The other was addressed to

16 Correspondance des directeurs de l'Académie de France à Rome, vol. 1, 40-41; Lapauze, Histoire de l'Académie de France, 37.

17 On travel routes in the region at the time: Bolard, Le voyage des peintres, 31, 37, 43-44; René Crozet, La vie artistique en France au XVIIe siècle (1598-1661). Les artistes et la société (Paris: Presses universitaires de France, 1954), 10.

18 Ennemond Servien reported to Colbert: "jay chargé un Gentilhomme de ma Maison de le mener, ainsy que tous ceux qui sont avec luy, dans tous les lieux de cette ville où il y a quelque chose de curieux en peinture ou en sculpture; il a aussy esté à la Vénerie avec eux, et ils ont si bien profité du temps que, bien qu'ils n’ayent séjourné icy que lundy, ils nont pas laissé de voir tout ce qu'il y a de rare et de beau.": Paris, Bibliothèque Nationale, Département des manuscrits, Colbert, Volumes verts, C. Cf.: Correspondance des directeurs de l’Académie de France à Rome, vol. 1, 40-41; Hryszko, "Podróż artystyczna Aleksandra Ubeleskiego," 57.

19 Cf. note 7.

20 One can read about places worth seeing in Turin in a guidebook from 1656: Pierre $\mathrm{Du}$ Val, Le Voyage et la Description d'Italie montrant exactement les raretez \& choses remarquables qui se trouvent es Provinces \& en châques Villes, les distances d'icelles; Avec un dénombrement des Places \& Champs de Batailles qui s'y sont donées (Paris: Chez Gervais Clovzier, 1656), 59-60.

21 "J'ay escrit aussy à l'abbé Servient, à Rome, sur le mesme sujet, croyant ne pouvoir apporter trop d'application à bien exécuter tous vos commandemens": Correspondance des directeurs de l'Académie de France à Rome, vol. 1, 40-41; Hryszko, "Podróż 
the Jesuit Giampiero Graneri, a native of Turin who was then residing in Milan, where Coypel's group was headed. ${ }^{22}$

It is likely that the artists got there in the second half of December. Perhaps it was then that Noël Coypel had bonded with the friar showing them around Milan enough for him to decide three years later, in 1675, to send his then 15-year-old son Antoine, who had also met Graneri on his way to Rome, to study in the Lombardian capital. ${ }^{23}$

Although sources are silent on Coypel's stay in Bologna, the importance of this cultural center was such that surely the painter did not fail to carefully acquaint his students with Bolognese art. For the artists, a visit to the Academy founded by the Carracci family and highly regarded in the academic circles of the time, must have been particularly valuable. ${ }^{24}$

At the turn of the year, Noël Coypel arrived in Florence, where he contacted Luigi Strozzi ${ }^{25}$ and gave him the letter from Colbert. ${ }^{26}$ The Tuscan capital was another important artistic center of the time, ${ }^{27}$ where Coypel, following Colbert's advice, was able to point out works worthy of imitation to his protégés, for example in the Galleria degli Uffizi, as well as in Florentine churches and palaces. In keeping with Colbert's educational goals for the trip, the Prix de Rome winners, led by Coypel, were also able to admire the interiors of private Florentine palaces. Unfortunately, the sources do not state what kind of palazzi they were.

artystyczna Aleksandra Ubeleskiego," 57. Mentions of H.-H. Servien can be found in: L'Italie en 1671. Relation d'un voyage du Marquis de Seignelay, suivie de lettres inédites à Vivonne, Du Quesne, Tourville, Fénelon et précédée d’une étude historique par Pierre Clément (Paris: Librairie Académique, 1867), 98.

22 "J'ay donné ensuite audit Sr Coypel une mienne lettre pour le P.[ère] Granery, Jésuite Piémontois, qui demeure à Milan et qui est frère de l'Intendant des finances de la Savoye. Il est de mes amis et ayme fort les François, de sorte que je ne doute pas qu'il ne contribue à luy faire voir audit Milan tout ce qu'il y a qui le mérite": Correspondance des directeurs de l’Académie de France à Rome, vol. 1, 40-41; Hryszko, "Podróż artystyczna Aleksandra Ubeleskiego," 57.

23 Correspondance des directeurs de l'Académie de France à Rome, vol. 1, 51-52. Young students of art were often sent to Milan: Lapauze, Histoire de l'Académie de France, 38, 51-52; Bolard, Le voyage des peintres, 67-68.

24 Artistic treasures of Bologna are described, among others, in: Du Val, Le Voyage et la Description d'Italie, 305-310.

25 Cf.: Jean Alazard, L’abbé Luigi Strozzi, correspondant artistique de Mazarin, de Colbert, de Louvois et de La Teulière. Contribution à létude des relations artistiques entre la France et l'Italie au XVIIe siècle (Paris: E. Champion, 1924).

26 Paris, Archives Nationale de France, Archives de la Marine, Dépêches concernant le commerce, 1672, fol. 330. Cf.: Correspondance des directeurs de l'Académie de France à Rome, vol. 1, 40 .

27 Cf.: Bolard, Le voyage des peintres, 83-86. 
At the end of January 1673, Coypel with his students arrived at his destination, where he took up his post as rector of the French Academy on the hill of Janiculum, near the monastery of Sant'Onofrio. ${ }^{28}$ Immediately after his arrival in Rome, Coypel, in fulfillment of his teaching duties, made a report of the educational trip he was supervising. The report was presented at the Académie Royale de Peinture et de Sculpture in Paris, and the requirement to report on an artistic journey attests to how much importance was placed on this element of the education of artists working for King Louis XIV. ${ }^{29}$

The trek to Rome was both the culmination of an education received in Paris and a prize in the Prix de Rome competition, as well as an opportunity to experience works of art directly in the cities along the route. Their reputation was a magnet attracting the attention of artists, who often took the route through the Alps, even though it was more difficult (due to the terrain), more dangerous (due to robbers) and more timeconsuming than, for example, a boat journey. ${ }^{30}$

Additional problems were caused by the cold and humid climate, acutely unpleasant during the winter. ${ }^{31}$ And it was in winter when Coypel and his companions travelled to Rome. The route they took longer and more difficult - was chosen due to its educational and artistic value provided by the works of art in the towns along the way. The possibility to appreciate them was the reason why the route through the Alps was the one most frequently chosen by artists travelling from France to the Eternal City. Their artistic journey, first of all, was to be educational, even at the expense of comfort or safety.

The desire to admire the masterpieces of the towns along this demanding route was sufficient justification for Coypel for choosing it. The main aim of the journey was to extend the artistic education received by students at the Paris Academy. The extant correspondence reveals that during the trip Coypel's companions were mostly interested in painting and sculpture, which directly stemmed from their artistic

28 Castan, "Les premières installations de l'Académie," 161-162; Correspondance des directeurs de l'Académie de France à Rome, vol. 1, 43-44; Lecoy de La Marche, L'Académie de France à Rome, 12, 60; Alaux, L’Académie de France à Rome, 28; Lapauze, Histoire de l'Académie de France, 17-19, 36, 39-41. See also: Hryszko, "Podróż artystyczna Aleksandra Ubeleskiego," 54; eadem, Le Peintre du Roi. Aleksander Ubeleski, 42.

29 Procès-verbaux de l'Académie Royale de Peinture et de Sculpture 1648-1792, publiés pour la Société de l'Histoire de l'Art français d’apres les registres originaux conservés à l'École des Beaux-Arts par Anatole de Montaiglon, vol. 2, 1673-1688 (Paris: J. Baur, 1878), 5; Correspondance des directeurs de l'Académie de France à Rome, vol. 1, 46.

30 Bolard, Le voyage des peintres, 36-38.

31 Ibidem, 47. 
specialization. The letters of recommendation that Coypel had received proved beneficial, as they allowed the artists not only to visit the towns located on their route, but also to visit places usually inaccessible to outsiders. Thanks to this, the journey itself became a source of artistic inspiration. Journeying was an important element of the artistic education of young people, offering them a direct contact with masterpieces: it shaped artistic inventiveness, enriched the repertoire of the patterns they were familiar with, and introduced them to Italy's invaluable artistic heritage.

Although this journey was directly connected with his new post, Noël Coypel planned in a way that allowed him to see and show to his students as much as possible rather than to reach the final destination as quickly as possible. As a guide and teacher (paidagōgós - $\pi \alpha$ ı $\delta \alpha \gamma \omega \gamma o ́ \varsigma$ ), Coypel led his students and supervised their educational process during and through the journey. In the 17th century, the journey to the Eternal City was a part of painters' education (paideía - $\pi \alpha$ a $\delta \varepsilon i a)$. Coypel used this journey as an opportunity to demonstrate to his students the vital role played by a direct contact with a work of art and by experiencing it first-hand. The journey included sightseeing cities, churches and palaces, and admiring great art collections usually inaccessible to the public, access to which was granted to Coypel thanks to reference letters from important persons both in Paris and in Italy. Although the journey had primarily educational and artistic nature, it also served as a rite of passage, as it gradually prepared students for the experience of Rome - the centre of artistic life at that time. 


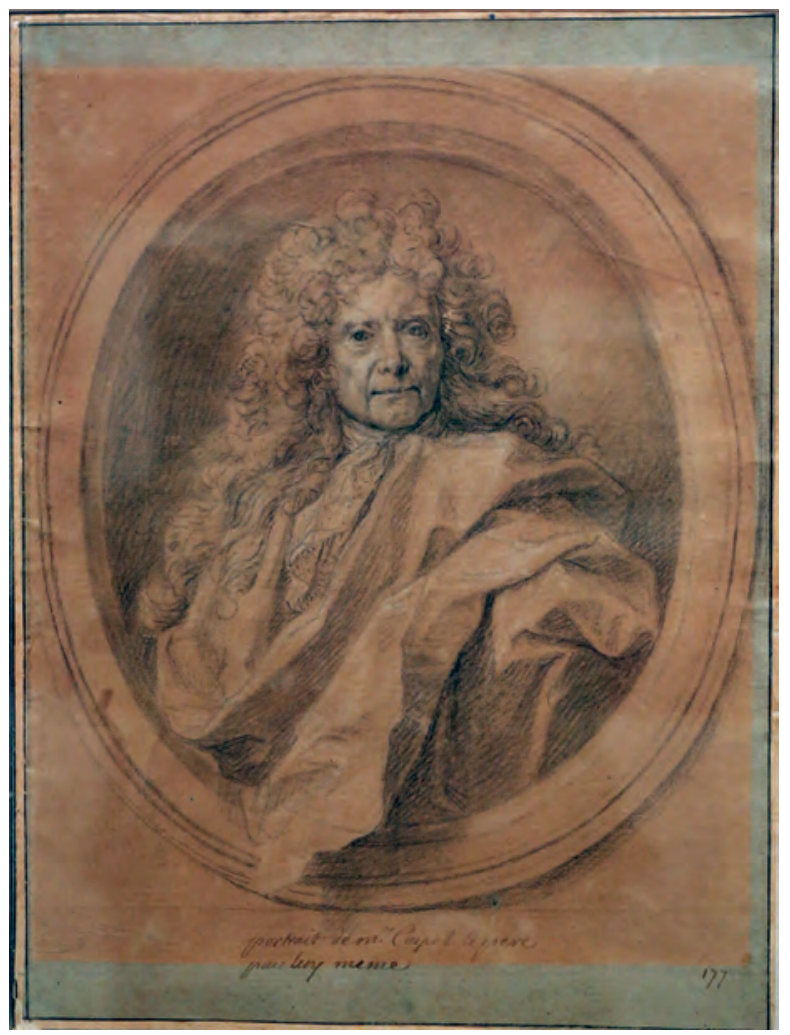

[Fig. 1]. Noël Coypel, Self-portrait, black stone and white chalk, Museum of Fine Arts of Rennes, Inv.794.1.2585, photo by Pymouss 


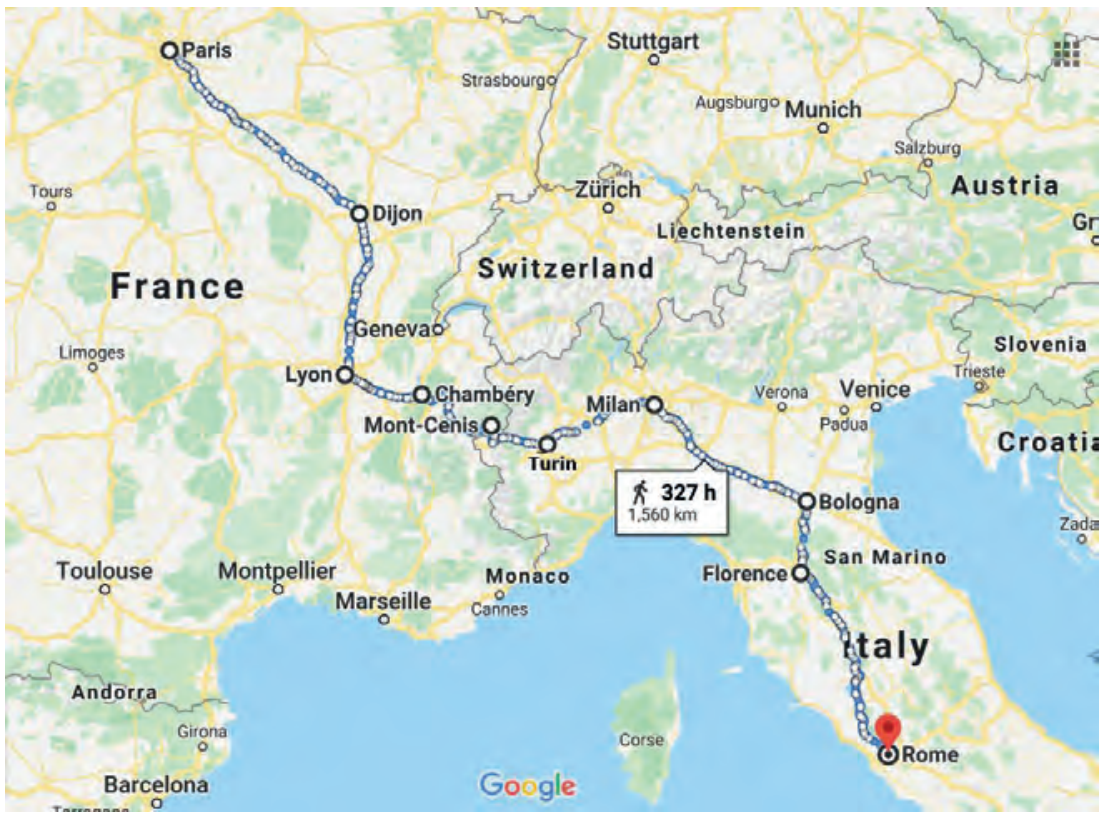

[Fig. 2]. Noël Coypel's journey to Rome (1672-1673)

\section{Bibliography}

\section{Archival sources}

Paris, Archives Nationale de France, Archives de la Marine, Dépêches concernant le commerce, 1672, fol. 329.

Paris, Archives Nationale de France, Archives de la Marine, Depéches concernant le commerce, 1672, fol. 330.

Paris, Bibliothèque Nationale, Département des manuscrits, Colbert, Volumes verts, C. Cf.: Correspondance des directeurs de l'Académie de France à Rome, vol. 1.

Paris, École Nationale Supérieure des Beaux-Arts, Ms. 1, Procès-verbaux de l'Académie royale de Peinture et de Sculpture, vol. 1.

Paris, École Nationale Supérieure des Beaux-Arts, Ms. 480, L'Etablissement de l'Académie royale de Peinture et de Sculpture. 


\section{Print sources}

Alazard Jean, L’abbé Luigi Strozzi, correspondant artistique de Mazarin, de Colbert, de Louvois et de La Teulière. Contribution à létude des relations artistiques entre la France et l'Italie au XVIIe siècle (Paris: E. Champion, 1924).

Comptes des Bâtiments du Roi sous le règne de Louis XIV, publiées par Jules Guiffrey, vol. 1, Colbert. 1664-1680 (Paris: Imprimerie Nationale, 1881).

Correspondance administrative sous le règne de Louis XIV entre le cabinet du roi, les secrétaires d'Etat, le chancelier de France et les intendants et gouverneurs des provinces, les présidents, procureurs et avocats généraux des parlements et autres Cours de Justice, par Georges Bernard Depping, vol. 4 (Paris: Imprimerie Nationale, 1855).

Correspondance des directeurs de l'Académie de France à Rome avec les Surintendants des Bâtiments, publiée par Anatole de Montaiglon, vol. 1, 1666-1694 (Paris: Charavay Frères, 1887).

Correspondance des directeurs de l'Académie de France à Rome avec les surintendants des bâtiments, publiée par Anatole de Montaiglon et Jules Guiffrey, vol. 6, 1721-1724 (Paris: Charavay Frères, 1896).

L'Italie en 1671. Relation d'un voyage du Marquis de Seignelay, suivie de lettres inédites à Vivonne, Du Quesne, Tourville, Fénelon et précédée d'une étude historique par Pierre Clément, (Paris: Librairie Académique, 1867).

Lecoy de La Marche Albert, L'Académie de France à Rome. Correspondance inédite de ses directeurs, précédée d'une étude historique (Paris: Didier, 1874).

Lettres, instructions et mémoires de Colbert publiés par Pierre Clément, vol. 5, Fortifications, Sciences, Lettres, Beaux-Arts, Bâtiments (Paris: Imprimerie Impériale, 1868).

Mémoires inédits et opuscules de Jean Rou (1638-1711), publiés pour la Société de l'histoire du protestantisme français, d'après le manuscrit conservé aux archives de l'État à La Haye par Francis Waddington (Paris: Agence centrale de la société, 1857).

Procès-verbaux de l'Académie Royale de Peinture et de Sculpture 1648-1792, publiés pour la Société de l'Histoire de l'Art français d'apres les registres originaux conservés à l'École des Beaux-Arts par Anatole de Montaiglon, vol. 1, 1648-1672 (Paris: J. Baur, 1875).

Procès-verbaux de l'Académie Royale de Peinture et de Sculpture 1648-1792, publiés pour la Société de l'Histoire de l'Art français d'apres les registres originaux conservés à l'École des Beaux-Arts par Anatole de Montaiglon, vol. 2, 1673-1688 (Paris: J. Baur, 1878).

\section{Monographs chapters}

Boutier Jean, "Le Grand Tour: Une pratique d'éducation des noblesses européennes (XVIe - XVIIIe siècles)," in Le Voyage à l'époque moderne, préface Lucien Bély (Paris: Presses de l'Université de Paris-Sorbonne, 2004), 7-22.

Brizay François, "La présentation de l'Italie dans les guides imprimés en français au XVIIe siècle," in Les guides imprimés du XVIe au XXe siècle. Villes, 
paysages, voyages. Actes du colloque tenu à Paris VII-Denis Diderot, les 3-5 décembre 1998, sous la direction de Gilles Chabaud, Évelyne Cohen, Natacha Coquery, Jérôme Penez (Paris: Belin, 2000), 359-376.

Brizay François, "Peut-on mesurer l'influence qu'eurent en France les guides et récits de voyage en Italie du milieu du XVIIe siècle à la fin du XVIIIe siècle?”, in La culture du voyage: pratiques et discours de la Renaissance à l'aube du XXe siècle, sous la direction de Gilles Bertrand (Paris: L'Harmattan, 2004), 121-146.

Montègre Gilles, “Artistes et voyageurs français à Rome à l'apogée du Grand Tour: les raisons dêtre d'une dépendance réciproque," in Voyage d'artistes en Italie du Nord XVIe-XIXe siècles, sous la direction de Véronique Meyer et Marie-Luce Pujalte-Fraysse (Rennes: Presses universitaires de Rennes, 2010), 33-44.

Thuillier Jacques, “"Il se rendit en Italie». Notes sur le voyage à Rome des artistes français au XVIIe siècle," in "Il se rendit en Italie». Etudes offertes à André Chastel (Rome-Paris: Elephante-Flammarion, 1987), 321-336.

\section{Monographs}

Alaux Jean-Paul, L’Académie de France à Rome. Ses directeurs, ses pensionnaires (Paris: Duchartre, 1933).

Bolard Laurent, Le voyage des peintres en Italie au XVIIe siècle (Paris: Les Belles Lettres, 2012).

Brilli Attilio, Le voyage d'Italie: histoire d'une grande tradition culturelle du XVI e au XIX e siècle (Paris: Flammarion, 1989).

Brizay François, Touristes du Grand Siècle. Le voyage d'Italie au XVIIème siècle (Paris: Belin, 2006).

Castiglione Minischetti Vito, Dotoli Giovanni, Musnik Roger, Le voyage français en Italie des origines au XVIIIe siècle: bibliographie analytique, Bibliothèque du voyage français en Italie, 1 (Fasano, Paris: Schena, Lanore, 2006).

Crozet René, La vie artistique en France au XVIIe siècle (1598-1661). Les artistes et la société (Paris: Presses universitaires de France, 1954).

Du Val Pierre, Le Voyage et la Description d'Italie montrant exactement les raretez \& choses remarquables qui se trouvent es Provinces \& en châques Villes, les distances d'icelles; Avec un dénombrement des Places \& Champs de Batailles qui s'y sont donées (Paris: Chez Gervais Clovzier, 1656).

Hryszko Barbara, Le Peintre du Roi. Aleksander Ubeleski (1649/1651-1718) malarz polskiego pochodzenia we Francji i jego dzieła (Kraków: WAM, Ignatianum, 2016).

La culture du voyage: pratiques et discours de la Renaissance à l'aube du XXe siècle, sous la direction de Gilles Bertrand (Paris: L'Harmattan, 2004).

Lapauze Henry, Histoire de l'Académie de France à Rome, vol. 1: 1666-1801 (Paris: Librairie Plon, 1924).

Schudt Ludwig, Italienreisen im 17. und 18. Jahrhundert, Römische Forschungen der Bibliotheca Hertziana, Band 15 (Wien, München: Schroll, 1959). 
Szanto Mickaël, Le dessin ou la couleur? Une exposition de peinture sous le règne de Louis XIV, préface d'Antoine Schnapper (Genève: Droz, 2008).

Valetta Franchi-Verney della, L’Académie de France à Rome, 1666-1903 (Paris: Fischbacher, 1904).

\section{Journal articles}

Castan Auguste, "Les premières installations de l'Académie de France à Rome d'après le plus ancien inventaire du mobilier et des travaux de cette institution," Mémoires de la Société démulation du Doubs, 4 (1889): 157-177.

Hryszko Barbara, "Podróż artystyczna Aleksandra Ubeleskiego z Paryża do Rzymu," Barok XX/2, 40 (2013): 47-58. 
